\title{
HIV infection is associated with higher levels of monocyte chemoattractant protein- 1 and eotaxin among people with recent hepatitis $C$ virus infection
}

François M. J. Lamoury ${ }^{1,6^{*}+}$, Behzad Hajarizadeh ${ }^{1 \dagger}$, Elizabeth Keoshkerian², Jordan J. Feld ${ }^{3}$, Janaki Amin ${ }^{1}$, Suzy Teutsch², Gail V. Matthews ${ }^{1,4}$, Margaret Hellard ${ }^{5}$, Gregory J. Dore ${ }^{1,4}$, Andrew R. Lloyd ${ }^{2}$, Tanya L. Applegate ${ }^{1+}$, Jason Grebely ${ }^{1 \dagger}$ and on behalf of the ATAHC Study Group

\begin{abstract}
Background: Human immunodeficiency virus (HIV) infection leads to more rapid progression of hepatitis $C$ virus (HCV)-related liver fibrosis, which could be linked to differences in the severity of liver inflammation among HIV/HCV co-infected individuals compared to HCV mono-infected individuals.

This study assessed the association of HIV co-infection with pro-inflammatory and pro-fibrogenic cytokines and chemokines during recent HCV infection.

Methods: Participants from the ATAHC study, a prospective cohort of recent HCV infection, with detectable HCV RNA at the time of acute HCV detection were included. Concentrations of 27 plasma cytokines and chemokines were measured by multiplex immunoassays and compared between those with, and without, HIV co-infection.

Results: Out of 117 individuals with recent HCV infection included in analysis, 73 had HCV mono-infection and 44 had HIV/HCV co-infection. Individuals with HIV/HCV co-infection had significantly higher mean levels of eotaxin (1. 79 vs. $1.62 \mathrm{log} \mathrm{pg} / \mathrm{mL} ; P<0.001)$, monocyte chemotactic protein 1 (MCP-1; 2.10 vs. $1.98 \mathrm{log} \mathrm{pg} / \mathrm{mL} ; P<0.001$ ), and interferon-gamma inducible protein-10 (IP-10; 3.11 vs. $2.98 \mathrm{log} \mathrm{pg} / \mathrm{mL} ; P=0.013)$. Linear regression analyses adjusting for age, alanine transaminase (ALT), HCV RNA levels, and assay run, higher eotaxin levels were independently associated with HIV/HCV co-infection (adjusted $\beta$ : 0.12; 95\%Cl: 0.01, 0.24; $P=0.039$ ). Higher MCP-1 levels were also independently associated with HIV/HCV co-infection in adjusted analysis (adjusted $\beta: 0.11 ; 95 \% \mathrm{Cl}: 0.03,0.18 ; P=0.009$ ).
\end{abstract}

Conclusions: During recent HCV, those with HIV/HCV co-infection had a stronger pro-fibrogenic mediator profile compared to those with HCV mono-infection. These findings may provide a potential explanation for accelerated liver fibrosis in HIV/HCV co-infection.

Trial registration: Australian Trial in Acute Hepatitis C (ATAHC) study was registered with ClinicalTrials.gov registry on September 11, 2005. NCT00192569.

Keywords: HCV, Cytokines, Chemokines, Co-infection, Acute infection

\footnotetext{
* Correspondence: flamoury@kirby.unsw.edu.au

${ }^{\dagger}$ Equal contributors

${ }^{1}$ The Kirby Institute, UNSW Australia, Sydney, Australia

Giral Hepatitis Clinical Research Program, The Kirby Institute, UNSW Australia,

Sydney, NSW 2010, Australia

Full list of author information is available at the end of the article
} 


\section{Background}

Among people with chronic hepatitis $\mathrm{C}$ virus (HCV) infection, co-infection with human immunodeficiency virus (HIV) leads to accelerated liver fibrosis progression [1-5]. Several mechanisms have been suggested, including increased pro-fibrogenic cytokine expression and secretion, enhanced oxidative stress, increased hepatocyte apoptosis, and immunosuppression [1, 6-8], although there is no clear consensus.

One potential explanation for more rapid fibrosis progression among HIV/HCV co-infected individuals compared to $\mathrm{HCV}$ mono-infected individuals could be differences in the severity of hepatic inflammation, leading to fibrosis. In the setting of chronic HCV infection, it has been demonstrated that individuals with HIV/ HCV co-infection have higher levels of a number of proinflammatory cytokines and chemokines $[9,10]$. Further, it has been shown that intrahepatic mRNA levels of inflammatory cytokines are higher among people with $\mathrm{HIV} / \mathrm{HCV}$ co-infection as compared to $\mathrm{HCV}$ monoinfection [11]. In the setting of acute HCV infection, it has previously been demonstrated that higher levels of interferon-gamma inducible protein-10 (IP-10) levels are observed among people with HIV, compared to those without HIV infection [12]. However, there are little data evaluating other cytokine and chemokine levels in people with, and without, HIV co-infection with recent $\mathrm{HCV}$ infection.

The Australian Trial in Acute Hepatitis C (ATAHC) was a multicentre, prospective cohort study of the natural history and treatment of recent (acute and early chronic) HCV infection [13]. The aim of this study was to compare cytokine and chemokine levels in people with, and without, HIV co-infection who acquired $\mathrm{HCV}$ infection.

\section{Methods \\ Study participants}

In ATAHC, acute or early chronic HCV infection was defined by an initial positive anti-HCV antibody test within 6 months of enrolment and either 1) a negative anti-HCV antibody test within 2 years prior to the initial positive anti-HCV antibody test or 2) acute clinical hepatitis within 12 months before the initial positive anti-HCV antibody result. Acute clinical infection was defined by symptomatic seroconversion illness or peak alanine transaminase (ALT) level greater than $400 \mathrm{IU} / \mathrm{mL}$ at or before the time of $\mathrm{HCV}$ diagnosis. In the current study, ATAHC participants with available plasma samples and HCV RNA detected at the time of acute HCV detection (screening visit) were included. Cytokines and chemokines were measured in screening visit plasma samples using a multiplex assay (see below).

\section{Measurement of plasma cytokines and chemokines}

Three human cytokine multiplex bead array assay kits utilizing technology licensed by Luminex (Bio-Rad, Gladesville, Australia) measured the following cytokines and chemokines: interleukin-1b (IL-1b), IL-4, IL-6, IL-10, IL17A, IL-17F, IL-21, IL-22, IL-23, IL-25, IL-31, IL-33, interferon-gamma (IFN-g), soluble CD40 ligand (sCD40L), tumor necrosis factor alpha (TNF-a), (with Bio-Plex human TH17 15-plex), IL-2, IL-8, eotaxin-1 (or CCL11), IFN-g, interferon-gamma inducible protein-10 (IP-10, or CXCL10), monocyte chemotactic protein 1 (MCP-1, or CCL2), macrophages inflammatory proteins 1 alpha (MIP1a, or CCL3), MIP-1ß (or CCL4), RANTES (regulated upon activation normal T-cell expressed, and presumably secreted; or CCL5) (with Bio-Plex human cytokine Group I 9-plex) and IL-18, TNF- 3 , TNF-related apoptosis-inducing ligand (TRAIL, or TNFSF10) (with Bio-Plex human cytokine Group II 3-plex).

The protocol was performed as per the manufacturer's instructions and previously described [14, 15]. Samples were centrifuged at $10,000 \mathrm{x}$ g for $10 \mathrm{~min}$ at $4{ }^{\circ} \mathrm{C}$ to remove platelets and precipitates, after which the supernatants were diluted four times with assay diluents. The assay was performed using all the assay components provided in a 96-well filter plate. The raw data was analysed using the Bio-Plex Manager software, v6.1 (Bio-Rad) [16].

\section{Statistical analysis}

$\log _{10}$ transformed values of cytokines levels $\left(\log _{10}\right.$ $\mathrm{pg} / \mathrm{mL}$ ) were used in analysis given the distribution of the actual values were not normal. The mean of plasma cytokine levels were compared between individuals with and without HIV co-infection (Student $T$ test). If the plasma cytokine level was below the level of detection, the midpoint between zero and the lowest level of reliable detection was imputed (Additional file 1: Table S1). Plasma levels of four cytokines (IL-23, IFN-g, TNF-b, and MIP-1a) were undetectable in $\geq 20 \%$ of individuals, for which proportion of individuals with undetectable cytokine level was compared between individuals with, and without, HIV co-infection (Chi-squared test).

Overall, 27 comparisons of plasma cytokines levels were conducted between two groups of individuals with, and without, HIV co-infection. Whether adjustments are needed for multiple comparisons is a matter of controversy given that multiple comparison testing might inflate type 1 error while adjustments for multiple comparisons inflate type 2 error [17-20]. To account for multiple comparisons, a moderately conservative significance level (alpha $=0.01)$ was used. In a sensitivity analysis, using Bonferroni correction for multiple 
comparisons, an alpha $=0.05 / 27=0.002$ was also used, but the findings were similar.

Two cytokines (i.e., MCP-1 and eotaxin) which had significantly different means between individuals with, and without, HIV co-infection were included in linear regression analysis. Linear regression models were fitted to assess the association of HIV coinfection with each plasma cytokine levels (log pg/mL). In the adjusted models, the association of these two cytokines and HIV co-infection was adjusted for potential confounders including age, ALT levels, and HCV RNA level at the time of acute $\mathrm{HCV}$ detection. Potential confounders were the variables associated with either HIV status or plasma cytokine levels in this study. To account for potential unmeasured confounders introduced by different assay runs and sample set, the models were also adjusted for assay set. All analyses were performed using Stata v12.0 (College Station, TX, United States).

\section{Results}

\section{Participant characteristics}

A total of 117 individuals with recent $\mathrm{HCV}$ infection were included in the study, including 44 (38 \%) with and 73 without (62\%) HIV co-infection. Background characteristics of the study population are summarized in Table 1. All individuals with HIV co-infection were male. Compared to individuals without HIV, those with HIV co-infection were significantly older, had a higher ALT level and had a greater proportion with high HCV RNA levels $(\geq 400,000 \mathrm{IU} / \mathrm{mL})$ at the time of recent $\mathrm{HCV}$ detection (Table 1). Two participants had HBV coinfection (positive HBsAg), both with no HIV coinfection.

Among 44 individuals with HIV co-infection, 24 (55\%) had HIV viral suppression $(\leq 50 \mathrm{IU} / \mathrm{ml})$ at the time of recent $\mathrm{HCV}$ detection. Among those with no HIV viral suppression, the median HIV RNA levels at the time of recent $\mathrm{HCV}$ detection was $4400 \mathrm{IU} / \mathrm{mL}$ (inter quartile range: 400,33467$)$. CD4 count at the time of acute HCV detection was $\geq 500$ cells $/ \mu \mathrm{L}$ in 28 (64\%) individuals, and 200-499 cells/ $\mu \mathrm{L}$ in 14 (32\%) individuals (not available in two individuals). Thirty-three individuals $(75 \%)$ were on antiretroviral therapy at the time of acute HCV detection, among whom, 18 (55 \%) had HIV viral suppression.

During the follow-up, ten individuals (9\%) cleared HCV spontaneously, while 107 individuals (91\%) either progressed to chronic infection, or received treatment.

\section{Distribution of cytokines levels by HIV status}

The distribution of cytokine levels in individuals with, and without, HIV co-infection is summarized in Table 2. Individuals with $\mathrm{HIV}$ co-infection had significantly higher mean plasma levels of MCP-1 and eotaxin
Table 1 Baseline characteristics of ATAHC participants with detectable HCV RNA at the time of acute HCV detection, stratified by HIV status

\begin{tabular}{|c|c|c|c|c|}
\hline & $\begin{array}{l}\text { Total } \\
(n= \\
117)\end{array}$ & $\begin{array}{l}\text { No HIV co- } \\
\text { infection ( } n \\
=73)\end{array}$ & $\begin{array}{l}\text { HIV co- } \\
\text { infection } \\
(n=44)\end{array}$ & $P$ \\
\hline & $\mathrm{n}(\%)^{\mathrm{a}}$ & $n(\%)^{a}$ & $\mathrm{n}(\%)^{\mathrm{a}}$ & \\
\hline$\overline{S e x}$ & & & & $<0.001$ \\
\hline Male & $88(75)$ & $44(60)$ & $44(100)$ & \\
\hline Female & $29(25)$ & $29(40)$ & $0(0)$ & \\
\hline Mean age, year (SD) & $34(10)$ & $31(9)$ & $41(8)$ & $<0.001$ \\
\hline Symptomatic acute HCV & & & & 0.825 \\
\hline No & $68(58)$ & $43(59)$ & $25(57)$ & \\
\hline Yes & $49(42)$ & $30(41)$ & $19(43)$ & \\
\hline $\begin{array}{l}\text { ALT level at acute HCV } \\
\text { detection, } \log _{10} \mathrm{IU} / \mathrm{L}\end{array}$ & $\begin{array}{l}2.2 \\
(0.5)\end{array}$ & $2.1(0.5)$ & $2.4(0.5)$ & 0.006 \\
\hline $\begin{array}{l}\text { Estimated duration of } \\
\text { infection at acute HCV } \\
\text { detection }\end{array}$ & & & & 0.236 \\
\hline$<26$ weeks & $69(59)$ & $40(55)$ & $29(66)$ & \\
\hline$\geq 26$ weeks & $48(41)$ & $33(45)$ & $15(34)$ & \\
\hline $\begin{array}{l}\text { Interferon lambda } 4 \\
\text { genotype (rs12979860) }\end{array}$ & & & & 0.185 \\
\hline $\mathrm{TT} / \mathrm{CT}$ & $56(48)$ & $37(51)$ & $19(43)$ & \\
\hline $\mathrm{CC}$ & $59(50)$ & $37(49)$ & $23(53)$ & \\
\hline Unknown & $2(2)$ & $0(0)$ & $2(4)$ & \\
\hline $\begin{array}{l}\text { HCV RNA level at acute } \\
\text { HCV detection }\end{array}$ & & & & 0.031 \\
\hline$<400,000 \mathrm{IU} / \mathrm{mL}$ & $78(67)$ & $54(74)$ & $24(55)$ & \\
\hline$\geq 400,000 \mathrm{IU} / \mathrm{mL}$ & $39(33)$ & $19(26)$ & $20(45)$ & \\
\hline HCV genotype & & & & 0.682 \\
\hline Genotype 1 & $67(57)$ & $41(56)$ & $26(59)$ & \\
\hline Genotype 3 & $40(34)$ & $27(37)$ & $13(29)$ & \\
\hline Other genotypes ${ }^{b}$ & $8(7)$ & $4(5)$ & $4(9)$ & \\
\hline Unknown genotype & $2(2)$ & $1(1)$ & $1(2)$ & \\
\hline
\end{tabular}

Abbreviation: $S D$ standard deviation

apercentages indicate column percentages

b Including genotype $2(n=6)$, genotype $4(n=1)$ and mixed genotype $(n=1)$

compared to those without HIV $(P<0.001$; Fig. 1a and b). IP-10 also had higher mean plasma levels in those with HIV co-infection compared to those without HIV coinfection ( $P=0.013$; Fig. 1c).

In unadjusted linear regression analysis, HIV coinfection was significantly associated with higher plasma MCP-1 levels [log pg/mL; $\beta$ (estimated mean difference): 0.13 ; $95 \%$ CI: 0.06, 0.19; Table 3]. In the adjusted model, HIV co-infection remained highly significantly associated with higher MCP-1 levels $(\log \mathrm{pg} / \mathrm{mL}$; adjusted $\beta$ : 0.11; 95 \% CI: 0.03, 0.18; Table 3). 
Table 2 Plasma cytokine and chemokine levels among ATAHC participants with detectable HCV RNA at the time of acute HCV detection, stratified by HIV

\begin{tabular}{|c|c|c|c|}
\hline Cytokine & $\begin{array}{l}\text { No HIV co-infection } \\
(n=73)\end{array}$ & $\begin{array}{l}\text { HIV co-infection } \\
(n=44)\end{array}$ & $P$ \\
\hline IL-1 beta ${ }^{a}$ & $0.77(0.77)$ & $0.56(0.59)$ & 0.197 \\
\hline $\mathbb{I L}-2^{\mathrm{a}}$ & $1.11(0.12)$ & $1.09(0.13)$ & 0.427 \\
\hline $\mid L-4^{a}$ & $2.16(0.25)$ & $2.13(0.28)$ & 0.589 \\
\hline $\mathbb{I L}-6^{\mathrm{a}}$ & $1.60(0.63)$ & $1.60(0.64)$ & 0.977 \\
\hline $\mathbb{L L}-8^{\mathrm{a}}$ & $1.71(0.54)$ & $1.71(0.48)$ & 0.994 \\
\hline $\mid \mathrm{L}-10^{\mathrm{a}}$ & $2.16(0.66)$ & $1.94(0.72)$ & 0.100 \\
\hline $\mathbb{I L}-17 A^{a}$ & $2.05(0.53)$ & $1.89(0.70)$ & 0.212 \\
\hline $\mathbb{L L}-17 F^{a}$ & $2.34(0.49)$ & $2.17(0.56)$ & 0.088 \\
\hline $\mid L-18^{a}$ & $2.44(0.29)$ & $2.52(0.25)$ & 0.171 \\
\hline $\mid \mathrm{L}-21^{\mathrm{a}}$ & $3.13(0.55)$ & $3.07(0.56)$ & 0.566 \\
\hline $\mid \mathrm{L}-22^{\mathrm{a}}$ & $1.73(0.68)$ & $1.81(0.53)$ & 0.458 \\
\hline $1 \mathrm{~L}-23^{\mathrm{b}}$ & $16(22)$ & $14(32)$ & 0.252 \\
\hline $\mid \mathrm{L}-25^{\mathrm{a}}$ & $1.46(0.72)$ & $1.32(0.94)$ & 0.415 \\
\hline $\mid L-31^{a}$ & $2.58(0.51)$ & $2.53(0.61)$ & 0.641 \\
\hline $1 \mathrm{~L}-33^{\mathrm{a}}$ & $3.49(0.26)$ & $3.41(0.29)$ & 0.245 \\
\hline IFN-gamma ${ }^{a}$ & $2.62(0.36)$ & $2.68(0.39)$ & 0.417 \\
\hline IFN-gamma $2^{b}$ & $57(79)$ & $38(86)$ & 0.329 \\
\hline TNF-alpha ${ }^{a}$ & $1.30(0.47)$ & $1.27(0.47)$ & 0.776 \\
\hline TNF-beta $^{b}$ & $68(93)$ & $43(98)$ & 0.407 \\
\hline TRAIL $^{a}$ & $2.07(0.18)$ & $2.12(0.21)$ & 0.119 \\
\hline sCD40L ${ }^{a}$ & $2.89(0.26)$ & $2.90(0.25)$ & 0.865 \\
\hline $\operatorname{CXCL10}(\mathrm{IP}-10)^{\mathrm{a}}$ & $2.98(0.24)$ & $3.11(0.28)$ & 0.013 \\
\hline $\operatorname{CCL} 2(\mathrm{MCP}-1)^{\mathrm{a}}$ & $1.98(0.17)$ & $2.10(0.19)$ & $<0.00$ \\
\hline CCL3 (MIP-1a) b & $36(49)$ & $16(36)$ & 0.172 \\
\hline $\mathrm{CCL} 4(\mathrm{MIP}-1 \mathrm{~b})^{\mathrm{a}}$ & $2.62(0.24)$ & $2.70(0.32)$ & 0.158 \\
\hline CCL5 (RANTES) ${ }^{a}$ & $3.78(1.66)$ & $3.94(1.56)$ & 0.606 \\
\hline CCL11 (eotaxin) ${ }^{a}$ & $1.62(0.30)$ & $1.79(0.21)$ & $<0.00$ \\
\hline
\end{tabular}

a Presented as mean plasma level (standard deviation); $\log _{10} \mathrm{pg} / \mathrm{mL}$

${ }^{b}$ Presented as the number with undetectable plasma level (\%)

In unadjusted linear regression analysis, HIV coinfection was also significantly associated with higher plasma eotaxin levels (log pg/mL; $\beta$ : 0.17; 95 \% CI: 0.07, 0.28; Table 4). In the adjusted model, HIV co-infection remained significantly associated with higher eotaxin levels (log pg/mL; adjusted $\beta$ : 0.12; 95 \% CI: 0.01, 0.24; Table 4).

Given that there were no females with HIV coinfection, models were not adjusted for sex. However, in a sensitivity analysis restricting the study population to males, a similar trend was observed with respect to the relationship between HIV infection and both MCP-1 (Additional file 1: Table S2) and eotaxin (Additional file 1: Table S3).

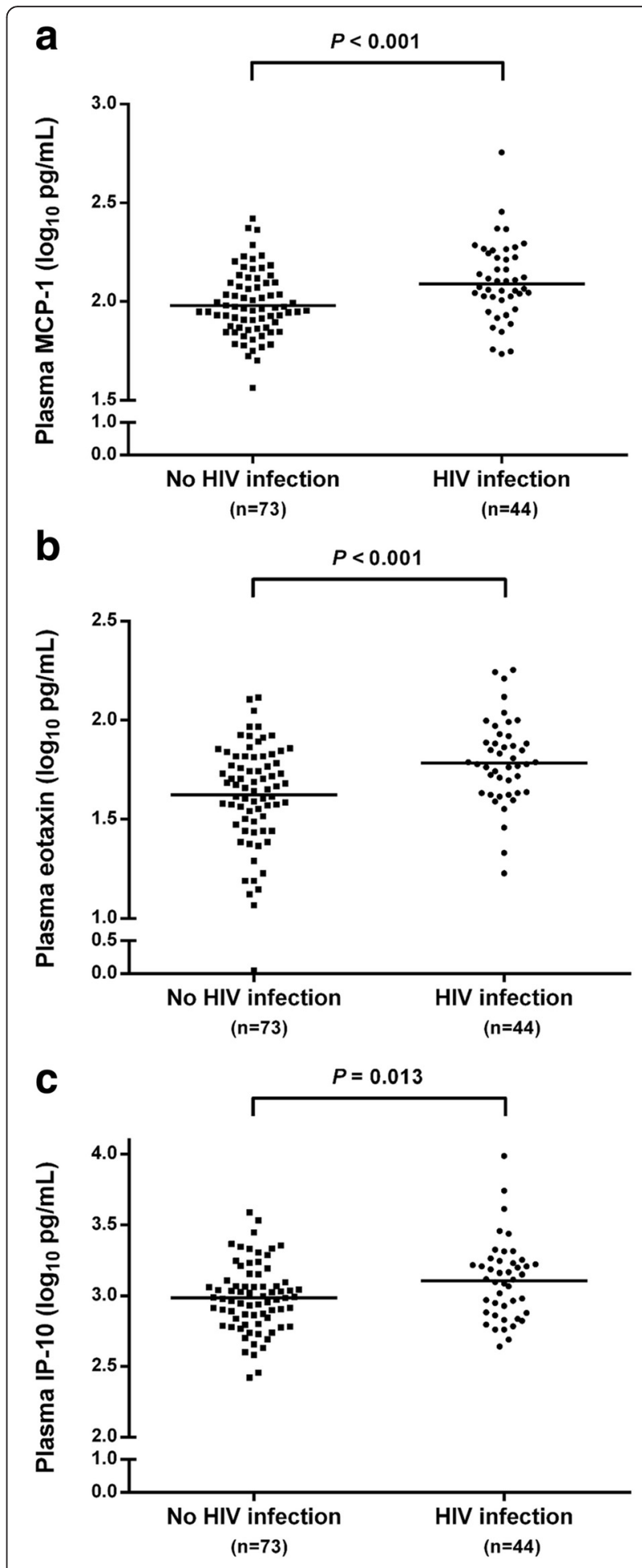

Fig. 1 Distribution of MCP-1 (a), eotaxin (b) and IP-10 (c) plasma levels among ATAHC participants with detected HCV RNA at acute HCV detection, by HIV status. Horizontal lines represent the mean

Among individuals with HIV co-infection, the mean plasma levels of MCP-1 and exotoxin among individuals with CD4 count $\geq 500$ cells $/ \mu \mathrm{L}$ were $2.12 \log \mathrm{pg} / \mathrm{mL}$ 
Table 3 Unadjusted and adjusted models assessing the association of HIV co-infection with plasma MCP-1 levels (log $10 \mathrm{pg} / \mathrm{mL}$ ) in ATAHC

\begin{tabular}{|c|c|c|c|c|}
\hline & \multicolumn{2}{|l|}{ Unadjusted model } & \multicolumn{2}{|l|}{ Adjusted model ${ }^{a}$} \\
\hline & Estimated mean difference ${ }^{\mathrm{b}}(95 \% \mathrm{Cl}$ ) & $P$ & Estimated mean difference ${ }^{\mathrm{b}}(95 \% \mathrm{Cl})$ & $P$ \\
\hline \multicolumn{5}{|l|}{ HIV co-infection } \\
\hline Negative & Reference & & Reference & \\
\hline Positive & $0.13(0.06,0.19)$ & $<0.001$ & $0.11(0.03,0.18)$ & 0.009 \\
\hline Age, 10 years & $0.04(0.00,0.07)$ & 0.024 & $0.01(-0.03,0.05)$ & 0.575 \\
\hline \multicolumn{5}{|c|}{ Symptomatic acute HCV } \\
\hline No & Reference & & & \\
\hline Yes & $0.06(-0.01,0.13)$ & 0.080 & & \\
\hline ALT level, log IU/L & $0.07(0.00,0.14)$ & 0.049 & $0.02(-0.05,0.10)$ & 0.502 \\
\hline \multicolumn{5}{|c|}{ Estimated duration of infection } \\
\hline$<26$ weeks & Reference & & & \\
\hline$\geq 26$ weeks & $-0.05(-0.12,0.02)$ & 0.196 & & \\
\hline \multicolumn{5}{|c|}{ Interferon lambda rs 12979860 genotype } \\
\hline $\mathrm{TT} / \mathrm{CT}$ & Reference & & & \\
\hline $\mathrm{CC}$ & $0.01(-0.06,0.08)$ & 0.809 & & \\
\hline \multicolumn{5}{|l|}{ HCV RNA level } \\
\hline$<400,000 \mathrm{IU} / \mathrm{mL}$ & Reference & & Reference & \\
\hline$\geq 400,000 \mathrm{IU} / \mathrm{mL}$ & $0.05(-0.02,0.12)$ & 0.181 & $0.02(-0.06,0.10)$ & 0.623 \\
\hline \multicolumn{5}{|l|}{ HCV genotype ${ }^{c}$} \\
\hline Genotype 1 & Reference & & & \\
\hline Genotype 3 & $0.00(-0.07,0.08)$ & 0.937 & & \\
\hline Other & $0.09(-0.05,0.23)$ & 0.222 & & \\
\hline
\end{tabular}

${ }^{a}$ Adjusted for variables associated with MCP-1 levels in unadjusted analysis or HIV status (i.e. age, ALT levels, and HCV RNA levels) as well as assay run $\left(n=117, R^{2}=0.14\right)$

${ }^{\mathrm{b}} \beta$ coefficient

'Overall $P=0.467$

[standard deviation (SD): 0.21] and $1.78 \mathrm{log} \mathrm{pg} / \mathrm{mL}(\mathrm{SD}$ : $0.19)$, respectively, which were comparable to $2.09 \log$ $\mathrm{pg} / \mathrm{mL}$ (SD: 0.18 ) and $1.83 \mathrm{log} \mathrm{pg} / \mathrm{mL}$ (SD: 0.27), respectively among those with CD4 count 200-499 cells/ $\mu \mathrm{L}(P=0.627$ and $P=0.524$, respectively).

In another analysis, the association of estimated of duration of $\mathrm{HCV}$ infection at the time of $\mathrm{HCV}$ detection with plasma cytokines levels were assessed (Additional file 1: Table S4). The mean plasma levels of IL-2 was significantly higher in individuals with an estimated of duration of HCV infection $\geq 26$ weeks $(1.07 \mathrm{log} \mathrm{pg} / \mathrm{mL}$; SD: $0.08)$ compared to those with an estimated of duration of $\mathrm{HCV}$ infection <26 weeks $(1.15 \mathrm{log} \mathrm{pg} / \mathrm{mL}$; SD: 0.15 ; $P=0.001)$.

\section{Discussion}

This study assessed the association of plasma cytokine and chemokine levels with HIV co-infection among individuals with recent $\mathrm{HCV}$ infection. HIV/HCV coinfection was independently associated with higher plasma levels of two pro-inflammatory and pro- fibrogenic chemokines, MCP-1 and eotaxin. Increased plasma levels of MCP-1 and eotaxin in $\mathrm{HIV} / \mathrm{HCV}$ coinfection might reflect increased hepatic expression of these cytokines and a subsequent chronic proinflammatory response [21, 22].

Individuals with $\mathrm{HIV} / \mathrm{HCV}$ co-infection and recent $\mathrm{HCV}$ infection in this study had significantly higher MCP-1 plasma levels compared to those with $\mathrm{HCV}$ mono-infection, which is consistent with findings in the setting of chronic HCV infection [9]. Similar findings in the setting of recent $\mathrm{HCV}$ infection are important and suggest that elevated levels of MCP-1 in HIV/HCV coinfected individuals occur early following $\mathrm{HCV}$ infection. A previous study has shown that MCP-1 plasma levels were elevated in HIV infection and correlated with HIV RNA levels [23]. However, MCP-1 plasma levels in the current study were comparable between HIV co-infected individuals with and without HIV viral suppression.

$\mathrm{C}-\mathrm{C}$ chemokine receptor 2 (CCR2) and its main ligand MCP-1 (CCL2) have major roles in promoting the accumulation and activation of monocyte-macrophages in 
Table 4 Unadjusted and adjusted models assessing the association of HIV co-infection with plasma eotaxin levels (log $10 \mathrm{pg} / \mathrm{mL}$ ) in ATAHC

\begin{tabular}{|c|c|c|c|c|}
\hline & \multicolumn{2}{|l|}{ Unadjusted model } & \multicolumn{2}{|l|}{ Adjusted model $^{a}$} \\
\hline & Estimated mean difference $^{\mathrm{b}}(95 \% \mathrm{Cl})$ & $P$ & Estimated mean difference $^{\mathrm{b}}(95 \% \mathrm{Cl})$ & $P$ \\
\hline \multicolumn{5}{|l|}{ HIV co-infection } \\
\hline Negative & Reference & & Reference & \\
\hline Positive & $0.17(0.07,0.28)$ & $<0.001$ & $0.12(0.01,0.24)$ & 0.038 \\
\hline Age, 10 years & $0.08(0.03,0.13)$ & 0.001 & $0.06(0.00,0.12)$ & 0.039 \\
\hline \multicolumn{5}{|c|}{ Symptomatic acute HCV } \\
\hline No & Reference & & & \\
\hline Yes & $0.05(-0.05,0.16)$ & 0.309 & & \\
\hline ALT level, log IU/L & $0.03(-0.07,0.14)$ & 0.534 & $-0.02(-0.13,0.09)$ & 0.712 \\
\hline \multicolumn{5}{|c|}{ Estimated duration of infection } \\
\hline$<26$ weeks & Reference & & & \\
\hline$\geq 26$ weeks & $-0.05(-0.15,0.06)$ & 0.375 & & \\
\hline \multicolumn{5}{|c|}{ Interferon lambda rs 12979860 genotype } \\
\hline $\mathrm{TT} / \mathrm{CT}$ & Reference & & & \\
\hline $\mathrm{CC}$ & $0.05(-0.06,0.15)$ & 0.379 & & \\
\hline \multicolumn{5}{|l|}{ HCV RNA level } \\
\hline$<400,000 \mathrm{IU} / \mathrm{mL}$ & Reference & & Reference & \\
\hline$\geq 400,000 \mathrm{IU} / \mathrm{mL}$ & $0.01(-0.10,0.13)$ & 0.791 & $-0.02(-0.14,0.09)$ & 0.689 \\
\hline \multicolumn{5}{|l|}{ HCV genotype ${ }^{c}$} \\
\hline Genotype 1 & Reference & & & \\
\hline Genotype 3 & $-0.08(-0.19,0.04)$ & 0.184 & & \\
\hline Other & $0.02(-0.19,0.23)$ & 0.860 & & \\
\hline
\end{tabular}

${ }^{a}$ Adjusted for variables associated with eotaxin levels in unadjusted analysis or HIV status (i.e. age, ALT levels, and HCV RNA levels) as well as assay run

$\left(n=117, R^{2}=0.15\right)$

${ }^{\mathrm{b}} \beta$ coefficient

'Overall $P=0.372$

the inflamed liver, as well as the activation of hepatic stellate cells (HSC) which are key drivers of fibrosis (reviewed in [24]). The role of CCR2 in promoting HSC chemotaxis and the development of hepatic fibrosis has been shown in animal models [25]. In humans, increased MCP-1 expression and CCR2-dependent macrophage infiltration in the liver [26, 27], and also higher MCP-1 plasma levels [28] have been found in the fibrotic liver. An MCP-1 gene polymorphism has been associated with increased expression of MCP-1 in the liver among individuals with chronic $\mathrm{HCV}$ and those with more advanced fibrosis [29]. In one longitudinal study, more rapid progression of hepatic fibrosis in $\mathrm{HCV}$ infection was correlated with persistent and significant elevation of MCP-1 plasma levels from acute to chronic infection [30]. Taken together, these data indicate the critical role of MCP-1 in development and progression of liver fibrosis. This existing evidence, coupled with our findings of increased MCP-1 plasma levels in $\mathrm{HIV} / \mathrm{HCV}$ coinfection suggest a potential explanation for accelerated liver fibrosis progression in $\mathrm{HIV} / \mathrm{HCV}$ co-infection, compared to $\mathrm{HCV}$ mono-infection. This hypothesis is supported by the in vitro data indicating that HIV can infect activated hepatic stellate cells (HSCs) to induce secretion of MCP-1 [31].

Knockout of CCR2 in mice results in reduced MCP-1 expression, diminished monocyte/macrophage infiltration and the development of lower levels of fibrosis following liver injury [32]. Further, data from animal models indicate that inhibition of MCP-1 reduces intrahepatic macrophage accumulation and development of steatohepatitis [21, 33]. Recently, Cenicriviric, a CCR2 and CCR5 antagonist, demonstrated good efficacy in suppressing HIV in phase IIb clinical trials [34, 35]. In addition to the antiretroviral effects, in animal models, Cenicriviric is anti-fibrotic, and reduces liver fibrosis progression [36]. One hypothesis is that the inhibition of MCP-1 might have therapeutic potential in reducing liver fibrosis progression in individuals with $\mathrm{HIV} / \mathrm{HCV}$ co-infection. This hypothesis is required to be supported by further research to evaluate the potential effect of inhibiting MCP-1 in reducing liver fibrosis. 
Individuals with $\mathrm{HIV} / \mathrm{HCV}$ co-infection and recent $\mathrm{HCV}$ infection in this study also demonstrated higher plasma eotaxin levels compared to those with $\mathrm{HCV}$ mono-infection. Eotaxin (CCL11) is a chemokine originally known as an eosinophil-specific chemoattractant which regulates eosinophil trafficking and facilitates eosinophil migration into the tissue by activating CCR3 receptors (reviewed in [37, 38]). Up-regulation of eotaxin expression has been demonstrated in the liver of individuals with drug-induced hepatitis and is accompanied by liver infiltration of eosinophils [39]. In the setting of $\mathrm{HCV}$ infection, increased plasma levels of eotaxin have been demonstrated in individuals with chronic HCV infection compared with healthy controls [40], while development of persistent $\mathrm{HCV}$ has also been found to be associated with higher plasma levels of eotaxin during acute infection [41]. Moreover, eotaxin has a role in hepatic fibrogenesis. Higher plasma eotaxin levels have been identified among individuals with liver cirrhosis, with higher eotaxin levels associated with increasing stage of fibrosis, and hepatic necro-inflammation and fibrosis by liver histology [42]. The observation that higher eotaxin plasma levels are observed in those with $\mathrm{HIV} / \mathrm{HCV}$ coinfection suggest that, similar to MCP-1, eotaxin might have a role in explaining accelerated liver fibrosis in individuals with $\mathrm{HIV} / \mathrm{HCV}$ co-infection.

This study had several limitations. First, this dataset was cross-sectional, then it was not possible to measure longitudinal levels of cytokines during acute $\mathrm{HCV}$ infection. Further, cytokine and chemokine concentrations were measured from plasma samples, so it is possible that the levels in the blood might not reflect hepatic levels. However, it has been demonstrated that intrahepatic and peripheral sources of MCP-1 are known to both contribute to elevated serum MCP-1 concentrations [22]. Data on liver fibrosis levels was not available in our participants. Further studies are needed to investigate the role of high MCP-1 and eotaxin levels in liver fibrosis progression among $\mathrm{HIV} / \mathrm{HCV}$ co-infected individuals. Lastly, multiple comparison testing might inflate type 1 error in data analysis. To account for this concern, a moderately conservative significance level (alpha $=0.01$ ) was used. We also conducted a sensitivity analysis, using Bonferroni correction for multiple comparisons (alpha $=0.05 / 27=0.002)$ but the findings were similar.

\section{Conclusion}

In conclusion, this study has demonstrated that compared to those without HIV infection, following acute $\mathrm{HCV}$ infection among people with HIV-infection, increased levels of the pro-fibrogenic chemokines, MCP-1 and eotaxin were observed. These findings could suggest a potential pathway possibly linking HIV infection with liver fibrogenesis among people with HIV/HCV infection. These findings may have also potential implications for therapeutic interventions to prevent liver fibrosis in people with $\mathrm{HIV} / \mathrm{HCV}$ co-infection.

\section{Additional file}

\begin{abstract}
Additional file 1: Table S1. The lowest level of detection for measurement of plasma cytokine and chemokine levels. Table S2. Unadjusted and adjusted models assessing the association of HIV co-infection with plasma MCP-1 levels among males in ATAHC $(n=88)$. Table S3. Unadjusted and adjusted models assessing the association of HIV co-infection with plasma eotaxin level among males in ATAHC $(n=88)$. Table S4. Plasma cytokine and chemokine levels among ATAHC participants with detectable HCV RNA at the time of acute HCV detection, stratified by estimated duration of HCV infection at the time of HCV detection. (DOCX $32 \mathrm{~kb}$ )
\end{abstract}

\section{Abbreviations}

ALT, alanine aminotransferase; ATAHC, Australian trial in acute hepatitis $C_{\text {; }}$ HCV, hepatitis C virus; IFN, interferon-gamma; IL, interleukin; IP-10, interferongamma inducible protein-10; IQR, inter-quartile range; MCP, monocyte chemotactic protein; MIP, macrophage inflammatory protein; RANTES, regulated upon activation normal T-cell expressed and presumably secreted; sCD40L, soluble CD40 ligand; TNF, tumor necrosis factor; TRAIL, TNF-related apoptosis-inducing ligand

\section{Acknowledgements \\ We would like to thank participants and all members of the ATAHC study group, including nurses, investigators, co-ordinators and research staff.}

\section{Funding}

This work was supported by the National Health and Medical Research Council (NHMRC) grant HIV and HCV vaccines and immunopathogenesis (\#510448) and UNSW Goldstar research grant. The ATAHC study was supported by the National Institutes of Health (\#RO1 DA 15999-01). The Kirby Institute is funded by the Australian Government Department of Health and Ageing and is affiliated with the Faculty of Medicine, UNSW Australia. $\mathrm{GD}$ is recipient of the NHMRC practitioner fellowship. JG is recipient of the NHMRC Career Development Fellowship.

\section{Availability of data and materials}

Additional data are available as supplementary materials. All raw data are available by request to corresponding authors.

\section{Authors' contributions}

GJD, GVM, MH, and ARL designed the original ATAHC study and wrote the protocol. BH, FMJL, JG, TLA, GJD, JJF, and ARL designed the current study. GJD, GVM, JG, BH ARL and ST provided samples and clinical data. FMJL and EK performed all laboratory work with input from TLA. BH and FMJL drafted the primary analysis plan, which was reviewed by JG, TLA, and JA. The primary analysis was conducted by BH which was reviewed by JG and JA. $\mathrm{BH}, \mathrm{FMJL}, J \mathrm{G}$, and TLA wrote the first draft of the article. All authors contributed to and approved the final article.

\section{Competing interests}

The authors declare that they have no competing interests.

\section{Consent to publish}

Not applicable.

\section{Ethical approval}

The ATAHC protocol was reviewed and approved by Human Research Ethics Committees of St. Vincent's Hospital, Sydney and the University Health Network, and all patients provided informed written consent. The study was registered with clinicaltrials.gov registry (NCT00192569). This study on chemokines and cytokines has been specifically approved by the St Vincent's Hospital Human Research Ethics Committee (HREC ref\#HCV12612. LNR/12/SVH/223). 


\section{Author details}

${ }^{1}$ The Kirby Institute, UNSW Australia, Sydney, Australia. ${ }^{2}$ Inflammation and Infection Research Centre, School of Medical Sciences, UNSW Australia, Sydney, Australia. ${ }^{3}$ Toronto Centre for Liver Disease, McLaughlin-Rotman Centre for Global Health, University of Toronto, Toronto, Canada. ${ }^{4}$ HIV/ Immunology/Infectious Diseases Clinical Services Unit, St Vincent's Hospital, Sydney, Australia. ${ }^{5}$ Burnet Institute, Melbourne, Australia. ${ }^{6}$ Viral Hepatitis Clinical Research Program, The Kirby Institute, UNSW Australia, Sydney, NSW 2010, Australia.

\section{Received: 9 November 2015 Accepted: 16 May 2016} Published online: 01 June 2016

\section{References}

1. Di Martino V, Rufat P, Boyer N, Renard P, Degos F, Martinot-Peignoux M, et al. The influence of human immunodeficiency virus coinfection on chronic hepatitis $C$ in injection drug users: a long-term retrospective cohort study. Hepatology. 2001;34(6):1193-9. doi:10.1053/jhep.2001.29201.

2. Goedert JJ, Eyster ME, Lederman MM, Mandalaki T, De Moerloose P, White 2nd GC, et al. End-stage liver disease in persons with hemophilia and transfusion-associated infections. Blood. 2002;100(5):1584-9.

3. Kirk GD, Mehta SH, Astemborski J, Galai N, Washington J, Higgins Y, et al. HIV, age, and the severity of hepatitis $C$ virus-related liver disease: a cohort study. Ann Intern Med. 2013:158(9):658-66. doi:10.7326/0003-4819-158-9201305070-00604.

4. Thein $\mathrm{HH}$, Yi Q, Dore GJ, Krahn MD. Natural history of hepatitis C virus infection in HIV-infected individuals and the impact of HIV in the era of highly active antiretroviral therapy: A meta-analysis. AIDS. 2008;22(15):1979-91.

5. Macías J, Berenguer J, Japón MA, Girón JA, Rivero A, López-Cortés LF, et al. Fast fibrosis progression between repeated liver biopsies in patients coinfected with human immunodeficiency virus/hepatitis $C$ virus. Hepatology. 2009;50(4):1056-63. doi:10.1002/hep.23136.

6. Lin W, Weinberg EM, Chung RT. Pathogenesis of Accelerated Fibrosis in HIV/HCV Co-infection. J Infect Dis. 2013;207 suppl 1:S13-8. doi:10.1093/ infdis/jis926.

7. Benhamou Y, Bochet M, Di Martino V, Charlotte F, Azria F, Coutellier A, et al. Liver fibrosis progression in human immunodeficiency virus and hepatitis C virus coinfected patients. The Multivirc Group. Hepatology. 1999;30(4):1054-8. doi:10.1002/hep.510300409.

8. Monto A, Kakar S, Dove LM, Bostrom A, Miller EL, Wright TL. Contributions to hepatic fibrosis in HIV-HCV coinfected and HCV monoinfected patients. Am J Gastroenterol. 2006;101(7):1509-15. doi:10.1111/j.1572-0241.2006.00613.x

9. Kushner LE, Wendelboe AM, Lazzeroni LC, Chary A, Winters MA, Osinusi $A$, et al. Immune biomarker differences and changes comparing HCV mono-infected, HIV/HCV co-infected, and HCV spontaneously cleared patients. PLoS One. 2013;8(4):e60387. doi:10. 1371/journal.pone.0060387.

10. Zeremski M, Dimova RB, Makeyeva J, Sipley JD, Jacobson IM, Rennert H, et al. IL28B polymorphism, pretreatment CXCL10, and HCV RNA levels predict treatment response in racially diverse HIV/HCV coinfected and HCV monoinfected patients. J Acquir Immune Defic Syndr. 2013;63(1):9-16. doi: 10.1097/QAl.0b013e31828323c1

11. Kuntzen T, Tural C, Li B, Feldmann G, Kupfer B, Nischalke HD, et al. Intrahepatic mRNA expression in hepatitis $C$ virus and HIV/hepatitis $C$ virus co-infection: infiltrating cells, cytokines, and influence of HAART. AIDS. 2008; 22(2):203-10. doi:10.1097/QAD.0b013e3282f3553b.

12. Grebely J, Feld JJ, Applegate T, Matthews GV, Hellard M, Sherker A, et al. Plasma interferon-gamma-inducible protein-10 (IP-10) levels during acute hepatitis C virus infection. Hepatology. 2013;57(6):2124-34. doi:10.1002/hep.26263

13. Dore GJ, Hellard M, Matthews GV, Grebely J, Haber PS, Petoumenos K, et al. Effective treatment of injecting drug users with recently acquired hepatitis C virus infection. Gastroenterology. 2010;138(1):123-35. doi:10.1053/j.gastro. 2009.09.019. e1-2.

14. O'Connor KA, Holguin A, Hansen MK, Maier SF, Watkins LR. A method for measuring multiple cytokines from small samples. Brain Behav Immun. 2004;18(3):274-80. doi:10.1016/j.bbi.2003.09.009.

15. Heijmans-Antonissen C, Wesseldijk F, Munnikes RJ, Huygen FJ, van der Meijden P, Hop WC, et al. Multiplex bead array assay for detection of 25 soluble cytokines in blister fluid of patients with complex regional pain syndrome type 1. Mediat Inflamm. 2006:2006(1):28398. doi:10.1155/MI/2006/28398.

16. Stacey AR, Norris PJ, Qin L, Haygreen EA, Taylor E, Heitman J, et al. Induction of a Striking Systemic Cytokine Cascade prior to Peak Viremia in Acute Human Immunodeficiency Virus Type 1 Infection, in Contrast to More Modest and Delayed Responses in Acute Hepatitis B and C Virus Infections. J Virol. 2009;83(8):3719-33. doi:10.1128/jvi.01844-08.

17. Perneger TV. What's wrong with Bonferroni adjustments. BMJ. 1998; 316(7139):1236-8. http://www.ncbi.n/m.nih.gov/pmc/articles/PMC1112991/ pdf/1236.pdf

18. Rothman KJ. No Adjustments Are Needed for Multiple Comparisons. Epidemiology. 1990;1(1):43-6.

19. Savitz DA, Olshan AF. Multiple Comparisons and Related Issues in the Interpretation of Epidemiologic Data. Am J Epidemiol. 1995;142(9):904-8

20. Thompson JR. Invited Commentary: Re: 'Multiple Comparisons and Related Issues in the Interpretation of Epidemiologic Data". Am J Epidemiol. 1998; 147(9):801-6. doi:10.1093/oxfordjournals.aje.a009530.

21. Baeck C, Wehr A, Karlmark KR, Heymann F, Vucur M, Gassler N, et al. Pharmacological inhibition of the chemokine CCL2 (MCP-1) diminishes liver macrophage infiltration and steatohepatitis in chronic hepatic injury. Gut. 2012;61(3):416-26. doi:10.1136/gutinl-2011-300304.

22. Fisher NC, Neil DA, Williams A, Adams DH. Serum concentrations and peripheral secretion of the beta chemokines monocyte chemoattractant protein 1 and macrophage inflammatory protein 1alpha in alcoholic liver disease. Gut. 1999:45(3):416-20.

23. Weiss L, Si-Mohamed A, Giral P, Castiel P, Ledur A, Blondin C, et al. Plasma levels of monocyte chemoattractant protein-1 but not those of macrophage inhibitory protein-1alpha and RANTES correlate with virus load in human immunodeficiency virus infection. J Infect Dis. 1997;176(6):1621-4

24. Tacke F. Functional role of intrahepatic monocyte subsets for the progression of liver inflammation and liver fibrosis in vivo. Fibrogenesis Tissue Repair. 2012:5 Suppl 1:S27.

25. Seki E, de Minicis S, Inokuchi S, Taura K, Miyai K, van Rooijen N, et al. CCR2 promotes hepatic fibrosis in mice. Hepatology. 2009;50(1):185-97. doi:10. 1002/hep.22952

26. Marra F, DeFranco R, Grappone C, Milani S, Pastacaldi S, Pinzani M, et al. Increased expression of monocyte chemotactic protein-1 during active hepatic fibrogenesis: correlation with monocyte infiltration. Am J Pathol. 1998;152(2):423-30.

27. Zimmermann HW, Seidler S, Nattermann J, Gassler N, Hellerbrand C Zernecke $\mathrm{A}$, et al. Functional Contribution of Elevated Circulating and Hepatic Non-Classical CD14 $<$ sup $>+</$ sup $>$ CD16 $<$ sup $>+</$ sup $>$ Monocytes to Inflammation and Human Liver Fibrosis. PLoS ONE. 2010;5(6): e11049. doi:10.1371/journal.pone.0011049.

28. Marsillach J, Bertran N, Camps J, Ferré N, Riu F, Tous M, et al. The role of circulating monocyte chemoattractant protein-1 as a marker of hepatic inflammation in patients with chronic liver disease. Clin Biochem. 2005; 38(12):1138-40. doi: http://dx.doi.org/10.1016/j.clinbiochem.2005.09.006.

29. Mühlbauer M, Bosserhoff AK, Hartmann A, Thasler WE, Weiss TS,

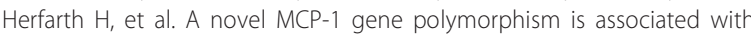
hepatic MCP-1 expression and severity of HCV-related liver disease. Gastroenterology. 2003;125(4):1085-93. doi: http://dx.doi.org/10.1016/ S0016-5085(03)01213-7.

30. Farci P, Wollenberg K, Diaz G, Engle RE, Lai ME, Klenerman P, et al. Profibrogenic chemokines and viral evolution predict rapid progression of hepatitis C to cirrhosis. Proc Natl Acad Sci. 2012;109(36):14562-7. doi:10. 1073/pnas.1210592109.

31. Tuyama AC, Hong F, Saiman Y, Wang C, Ozkok D, Mosoian A, et al. Human immunodeficiency virus (HIV)-1 infects human hepatic stellate cells and promotes collagen I and monocyte chemoattractant protein-1 expression: Implications for the pathogenesis of HIV/ hepatitis C virus-induced liver fibrosis. Hepatology. 2010;52(2):612-22. doi:10.1002/hep.23679

32. Mitchell C, Couton D, Couty J-P, Anson M, Crain A-M, Bizet V, et al. Dual Role of CCR2 in the Constitution and the Resolution of Liver Fibrosis in Mice. Am J Pathol. 2009;174(5):1766-75. doi: http://dx.doi.org/10.2353/ ajpath.2009.080632.

33. Parker R, Walters M, Ertl L, Ebsworth K, Tan J, McMahon J, et al. Therapeutic use of a clinical stage CCR2 inhibitor, CCX872, in obesityassociated steatohepatitis. Lancet. 2014;383:S78. doi:10.1016/S01406736(14)60341-X [abstract]. 
34. Gathe J, Cade J, De Jesus E, et al. Week-24 primary analysis of cenicriviroc vs efavirenz, in combination with emtricitabine/tenofovir, in treatment-naive HIV-1+ adults with CCR5-tropic virus. Atlanta: The 20th Conference on Retroviruses and Opportunistic Infections; 2013. 3-6 March. p. [abstract 106LB].

35. Feinberg J, Thompson M, Cade J, et al. Final week 48 analysis of cenicriviroc compared to efavirenz in combination with emtricitabine/tenofovir in treatment-naïve HIV-1-infected adults with CCR5-tropic virus. Brussels: The 14th EACS; 2013. 16-19 October. p. [abstract PS4/1].

36. Hong F, Chou H, Friedman SL. Significant anti-fibrotic activity of cenicriviroc a dual CCR2/CCR5 antagonist in a rat model of thioacetamide-induced liver fibrosis and cirrhosis. Hepatology. 2013;58(6):1381A [abstract].

37. Broide D, Sriramarao P. Eosinophil trafficking to sites of allergic inflammation. Immunol Rev. 2001;179(1):163-72. doi:10.1034/j.1600-065X. 2001.790116.x.

38. Lampinen M, Carlson M, Håkansson LD, Venge P. Cytokine-regulated accumulation of eosinophils in inflammatory disease. Allergy. 2004;59(8): 793-805. doi:10.1111/j.1398-9995.2004.00469.x.

39. Pham B-N, Bernuau J, Durand F, Sauvanet A, Degott C, Prin L, et al. Eotaxin expression and eosinophil infiltrate in the liver of patients with druginduced liver disease. J Hepatol. 2001;34(4):537-47. doi:http://dx.doi.org/10. 1016/S0168-8278(00)00057-X

40. Yoneda S, Umemura T, Joshita S, Ichijo T, Matsumoto A, Yoshizawa K, et al. Serum chemokine levels are associated with the outcome of pegylated interferon and ribavirin therapy in patients with chronic hepatitis C. Hepatol Res. 2011:41(6):587-93. doi:10.1111/j.1872-034X.2011.00802.x.

41. Osburn WO, Levine JS, Chattergoon MA, Thomas DL, Cox AL. Antiinflammatory cytokines, pro-fibrogenic chemokines and persistence of acute HCV infection. J Viral Hepat. 2013;20(6):404-13. doi:10.1111/jvh.12052.

42. Tacke F, Trautwein C, Yagmur E, Hellerbrand C, Wiest R, Brenner DA, et al. Up-regulated eotaxin plasma levels in chronic liver disease patients indicate hepatic inflammation, advanced fibrosis and adverse clinical course. J Gastroenterol Hepatol. 2007:22(8):1256-64. doi:10.1111/j.1440-1746.2006.04621.x.

\section{Submit your next manuscript to BioMed Central and we will help you at every step:}

- We accept pre-submission inquiries

- Our selector tool helps you to find the most relevant journal

- We provide round the clock customer support

- Convenient online submission

- Thorough peer review

- Inclusion in PubMed and all major indexing services

- Maximum visibility for your research

Submit your manuscript at www.biomedcentral.com/submit 